\title{
Animal performance and economic implications of alternative production systems for dairy bulls slaughtered at 15 months of age
}

\author{
B. Murphy ${ }^{1,2}$, P. Crosson ${ }^{1}$, A.K. Kelly ${ }^{2}$, R. Prendiville ${ }^{1 \dagger}$
}

${ }^{1}$ Animal \& Grassland Research and Innovation Centre, Teagasc Grange, Dunsany, Co. Meath, Ireland

Abstract

${ }^{2}$ School of Agriculture \& Food Science, University College Dublin, Belfield, Dublin 4, Ireland

The objectives of this experiment were to investigate (i) the influence of varying levels of concentrate supplementation during the grazing season, (ii) alternative finishing strategies for dairy bulls slaughtered at 15 mo of age and (iii) economic implications of these management strategies. Bulls were assigned to a 2 (level of concentrate supplementation during the grazing season: $1 \mathrm{~kg}$ [LA] and $2 \mathrm{~kg}$ [HA] dry matter [DM]/head daily) $\times 2$ (finishing strategies: concentrates ad libitum group [AL] or grass silage ad libitum plus $5 \mathrm{~kg} D M$ of concentrates/head daily group [SC]) factorial arrangement of treatments. Average daily gain $(A D G)$ during the grazing season was greater $(P<0.01)$ for HA than for LA. Consequently, HA bulls were $16 \mathrm{~kg}$ heavier at housing: 214 and $230 \mathrm{~kg}$, respectively $(P<0.05)$. During the finishing period, $A D G$ tended $(P=0.09)$ to be greater for LA than for HA. Carcass weight tended $(P=0.08)$ to be greater for HA than for LA. Fat score was greater for HA. Live weight at slaughter $(P<0.001)$ and carcass weight $(P<0.001)$ were 41 and $23 \mathrm{~kg}$ greater for $A L$ than for $S C$, respectively. Conformation $(P<0.05)$ and fat score $(P<0.05)$ were greater for $A L$ than for SC. The Grange Dairy Beef Systems Model simulated whole-farm system effects of the production systems. Net margin/head was greater for LA than for HA and greater for SC than for AL. Sensitivity analysis of finishing concentrate price, calf purchase price and beef price showed no re-ranking of the systems on a net margin basis. Although greater animal performance was observed from the Keywords higher plane of nutrition, overall profitability was lower.

carcass weight $\cdot$ dairy bulls $\bullet$ finishing strategies $\cdot$ pasture $\bullet$ profitability

\section{Introduction}

The abolition of European Union (EU) milk quota and the targeted $50 \%$ increase in milk production by 2020 (Department of Agriculture, Food and the Marine [DAFM], 2010) is expected to have a dramatic effect on Irish dairy production. This is likely to result in a greater proportion of male dairy calves becoming available for beef production (European Commission, 2015). Traditionally, pasture-based steer production systems have incorporated a winter finishing period, whereby animals were finished at 24 mo of age on a grass silage ad libitum diet plus concentrates (Keane and Allen, 1998; McGee et al., 2005). In practice, dairy steers account for $55 \%$ of total steer slaughterings and are finished during their third season at grass at 26-30 mo of age (O'Riordan and Cormican, 2015). More recently, there has been a significant increase in the proportion of bulls slaughtered, increasing from 3\% in 2002 to $13 \%$ in 2015 (Irish Food Board [Bord Bia], 2016a). Prior to decoupling of support premia in 2003, bull beef production was generally less profitable than well-managed steer beef production, largely due to the higher premium-earning capacity of steers (Swinbank and Daugbjerg, 2006). Since then, the biological advantage of bulls compared to steers (superior growth rate, feed efficiency, carcass muscle proportion and the subsequent reduction in age at slaughter; Steen, 1995) has been exploited by beef producers.

A further consideration is that current UK market specifications stipulate that dairy bulls be slaughtered at $<16 \mathrm{mo}$ of age, achieve a minimum carcass weight of $270 \mathrm{~kg}$ and have conformation and fat scores of ' $\mathrm{O}=$ ' and '2+' or greater, respectively (Dawn Meats, 2011). Given the importance of the UK market for Irish beef exports (Bord Bia, 2016b), it is essential that production blueprints meet these requirements. A shift from a 24-mo steer system to a more concentrate-intensive 15 -mo bull beef system would result in an alteration to the finishing strategy and sale date. Increased levels of concentrate input during the finishing period, typically a concentrates ad libitum diet, are necessary to reach an acceptable live weight at slaughter at a younger age (O'Riordan et al., 2011). While these concentrateintensive production systems appear attractive from an output perspective, feed costs can be considerable and, consequently, the profitability of such systems can be marginal, particularly when feed costs are high (Ashfield et al., 2014a). An economic modelling study by Ashfield et al. (2014a) reported that dairy

${ }^{+}$Corresponding author: R. Prendiville

E-mail: robert.prendiville@teagasc.ie 
bulls finished on concentrates ad libitum and slaughtered at 15 mo of age comprised the least profitable dairy calf-to-beef system investigated. Since grazed grass is a considerably cheaper feed source than grass silage or concentrates (Finneran et al., 2010), incorporating grazed grass into the feed budget with strategic concentrate supplementation is of interest.

Typically, under Irish conditions, calves are pasture-grazed during the first season, and moderate levels of performance are achieved (Campion et al., 2009). However, there is a paucity of available literature that evaluates concentrate supplementation at pasture for dairy calves. When animals are slaughtered at a younger age, concentrates constitute a larger proportion of the feed budget (O'Riordan et al., 2011). Dairy calves slaughtered at a younger age may require additional concentrate supplementation during their first season at pasture to enhance animal performance at pasture (Campion et al., 2009). Differences in alternative finishing strategies, including duration and diet, have been well documented (Sami et al., 2004; McGee et al., 2005). Binder et al. (1986) investigated differences in finishing diets and reported that grain-fed steers had a greater kill-out proportion, more intramuscular fat, greater conformation score and a whiter fat colour than forage-fed steers. Similarly, Cerdeño et al. (2006) reported that bulls finished with restricted feeding on concentrates had a lower fat score but produced meat of similar quality compared to bulls finished on a concentrates ad libitum diet. Although those studies examined alternative finishing strategies for dairy and dairy beef crossbred cattle, the ages at slaughter in those studies were greater than current market restrictions for bulls.

Supplementation of concentrates during the first season at pasture and alternative finishing strategies may have the potential to increase farm profit by improving calf performance at pasture and reducing the reliance on concentrates during the finishing phase. Therefore, the objectives of this study were to evaluate the effects of varying levels of concentrate supplementation during the first season at pasture and alternative finishing strategies on dairy bulls slaughtered at $15 \mathrm{mo}$ of age and to conduct an economic appraisal of these production systems.

\section{Materials and methods}

This study was carried out at the Teagasc Johnstown Castle Research Centre $\left(52^{\circ} 17^{\prime} \mathrm{N}, 6^{\circ} 30^{\prime} \mathrm{W}\right)$ on a permanent grassland sward of predominantly perennial ryegrass (Lolium perenne). The soil type was a mix of fine loamy with imperfect and moderate draining gley soils (Gardiner and Radford, 1980). Eighty-four spring-born dairy bull calves (51 Holstein-Friesian [HF] and 33 Jersey $\times$ HF [JEX]) were purchased from commercial dairy farms and artificially reared on site. Mean date of birth was 11 February 2011, and age at arrival was $18 \mathrm{~d}$ (s.d.: $8.3 \mathrm{~d}$ ). Calves were reared artificially and offered $30 \mathrm{~kg}$ of milk replacer similar to that described by Fallon (1992). At weaning, calves were assigned to one of four treatments in a 2 (levels of concentrate supplementation during the grazing season: $1 \mathrm{~kg}[\mathrm{LA}]$ or $2 \mathrm{~kg}[\mathrm{HA}] \mathrm{DM} / \mathrm{head}$ daily) $\times 2$ (finishing strategies: concentrates ad libitum (AL or grass silage ad libitum plus $5 \mathrm{~kg}$ DM of concentrates/head daily [SC]) factorial arrangement of treatments. Calves were assigned to treatment on 20 May, blocked by weaning weight, breed, farm of origin and date of birth. Calves were generated from 34 sires: $23 \mathrm{HFs}$ and 11 Jerseys. Sixty-nine calves were sired by artificial insemination using sires commonly available in Ireland; four calves were sired by stock bulls (sired one calf each) and 11 calves had unknown sires.

\section{Animal management}

Calves were randomly assigned to one of three grazing groups within each concentrate supplementation level and managed on a rotational grazing system during the grazing season, as described by O'Donovan et al. (2002). Sward quality was maintained by using strip fencing with excess pasture removed as baled silage. Target pre- and postgrazing sward heights were $10 \mathrm{~cm}$ and $4 \mathrm{~cm}$, respectively. Concentrate supplementation was offered in a single feed each morning. Calves were treated with Ivomec $1 \%$ injection (Merial Limited, Duluth, GA, USA) at 4, 8 and 12 wk after turnout to control internal parasites during the grazing season. Calves were pasture-grazed for 153 (s.d.: 14.2) d and housed on 3 November on slatted floor accommodation.

At housing, bulls were accommodated in replicated pens (three pens/treatment) until slaughter. Both $\mathrm{AL}$ and SC were gradually adapted to their finishing diets over a 21-d period. Fresh concentrates were offered daily to the AL group, and refusals were weighed back five times weekly. Straw was offered on an ad libitum basis to the AL group to ensure normal rumen function. Bulls in the SC treatment group were offered a grass silage ad libitum diet plus $5 \mathrm{~kg} \mathrm{DM} / \mathrm{d}$ of concentratebased total mixed ration. Bulls were slaughtered after a 205 (s.d.: 15.1)-d finishing period. Bulls were selected for slaughter on one of three slaughter dates based on the date of birth on their animal passport to ensure that bulls were $<16 \mathrm{mo}$ ( $460 \mathrm{~d}$; s.d.: $7.1 \mathrm{~d}$ ) of age. The concentrate ration offered throughout the experimental period consisted of $580 \mathrm{~g} / \mathrm{kg}$ barley, $260 \mathrm{~g} /$ $\mathrm{kg}$ beet pulp, $100 \mathrm{~g} / \mathrm{kg}$ soya bean meal, $40 \mathrm{~g} / \mathrm{kg}$ molasses and $20 \mathrm{~g} / \mathrm{kg}$ minerals.

Body weight was recorded fortnightly throughout the study, using a 'Weigh Crate' (O'Donovan's Engineering, Cork, Ireland) and the 'Winweigh' software package (Tru-test Limited, Auckland, New Zealand). Average daily gain (ADG) was calculated for each bull using linear regression of live 
weight against recording date. Bulls were weighed at housing and again $4 \mathrm{~d}$ later in an attempt to reduce the variation caused by gut-fill. On the morning of slaughter, bulls were transported a distance of $63 \mathrm{~km}$ for approximately $50 \mathrm{~min}$ to a commercial slaughter plant and weighed in the lairage approximately $1 \mathrm{~h}$ before slaughter using a portable 'Platform Weigher' (O'Donovan's Engineering) to determine kill-out proportions.

\section{Carcass assessment}

Hot carcass weight was determined on each carcass immediately before video imaging analysis (VIA), and cold carcass weight was subsequently calculated (hot carcass weight $\times 0.98)$. Perinephric and retroperitoneal fat was removed from the left and right sides of each carcass, weighed and recorded. Carcass conformation and fat scores were mechanically assigned to each carcass side using the EU Beef Carcass Classification Scheme (Commission of the European Communities, 1982). Carcasses were classified on a continuous 15-point scale using a VIA carcass classification system (VBS2000; E+V Technology, Oranienburg, Germany). Carcass measurements were recorded on the right-hand side of each carcass, as described by De Boer et al. (1974). Carcasses were hung from the Achilles tendon and stored for $48 \mathrm{~h}$ at $4^{\circ} \mathrm{C}$ before being de-boned. Carcasses were divided into fore and hind quarters, as described by Keane and Allen (1998). On the right-hand side of each carcass, the 5th-10th ribs were removed from the pistola by cutting between the 10 th and the $11^{\text {th }}$ ribs. The $M$. longissimus area was traced and calculated using the Java image processing programme (Schneider et al., 2012). The joint was then dissected into muscle (M. longissimus plus the other muscle proportion) and bone (including ligamentum nuchae).

\section{Feed analysis}

Grass and concentrate samples were collected weekly throughout the grazing season, with grass silage and concentrate samples collected weekly during the finishing period. Pre-grazing grass samples were collected for each rotation by cutting four quadrants $(0.5 \mathrm{~m} \times 0.5 \mathrm{~m})$, representative of each plot, using an electric shears (Accu Grass Shears Comfortcut, Gardena Ltd., Ulm, Germany), as described by O'Donovan et al. (2002). All feed samples were duplicated. The first sample was oven-dried at $100^{\circ} \mathrm{C}$ for $24 \mathrm{~h}$ to determine the DM. The second sample was oven-dried at $40^{\circ} \mathrm{C}$ for $48 \mathrm{~h}$ and milled in a $\mathrm{C} \& \mathrm{M}$ Junior laboratory mill (South Hackensack, New Jersey); $1 \mathrm{~mm}$ sieve) for chemical analysis. Grass and concentrate samples were pooled on a fortnightly basis, while grass silage samples were pooled on a monthly basis. Concentrate samples were analysed for starch, crude protein and ash. Analysis was carried out for in vitro DM digestibility, in vitro organic matter digestibility, crude protein and ash for the grass silage samples. Grass samples were analysed for crude ash, crude protein, in vitro DM digestibility, in vitro organic matter digestibility and water-soluble carbohydrates. Analysis was performed as described by Owens et al. (2008). Neutral detergent fibre was determined for all samples using the Ankom method (F57; Ankom Technology, Macedon, NY, USA).

\section{Economic analysis}

Bioeconomic modelling was carried out using the Grange Dairy Beef Systems Model (Ashfield et al., 2013), which is a whole-farm, single-year, static, deterministic simulation model that facilitates the technical and economic evaluation of grassland-based dairy calf-to-beef production systems. Biological performance from bulls in the current experiment was incorporated into the model. This included monthly live weight and concentrate DM intake (CDMI) data, carcass traits and housing requirements. Where data was not available from the current experiment, including those required to quantify variable costs (concentrate feed costs, fertiliser, silage, reseeding, slurry, straw, milk replacer, veterinary services and medicine, interest on working capital, marketing and transport) and fixed costs (building maintenance, machinery operation, land improvements, interest, depreciation, car, telephone and electricity), these were based on data from Connolly et al. (2010), Central Statistics Office (CSO) (2015) and O'Donovan and O'Mahony (2011). Default parameters for the model are outlined in Table 1. The economic analysis was based on a 20 ha land area with 200 purchased calves. Calves were taken through to slaughter in production systems based on the experimental treatments of the current study. The model assumed that grass silage was offered to the $\mathrm{AL}$ group during the finishing period to maintain normal rumen function. Beef carcass price was the actual price received on the day of slaughter. Sensitivity analysis was carried out

Table 1. Assumptions used in the Grange Dairy Beef Systems Model

\begin{tabular}{|c|c|}
\hline Item & Value \\
\hline \multicolumn{2}{|l|}{ Calf price $(€ /$ head $)$} \\
\hline Holstein-Friesian ${ }^{1}$ & 130 \\
\hline Jersey $\times$ Holstein-Friesian ${ }^{1}$ & 60 \\
\hline Milk replacer ${ }^{2}(€ / t)$ & 2,124 \\
\hline Calf rearing concentrate ${ }^{2}(€ / t)$ & 320 \\
\hline Finishing concentrate ${ }^{2}(€ / t)$ & 300 \\
\hline Grass silage (€/t DM) & 170 \\
\hline \multicolumn{2}{|l|}{ Mortality (\%/yr) } \\
\hline $0-12 \mathrm{mo}$ & 5 \\
\hline $13-24 \mathrm{mo}$ & 2 \\
\hline
\end{tabular}

${ }^{1}$ Irish Farmers Journal (IFJ) (2011).

${ }^{2}$ Central Statistics Office (2015).

$\mathrm{DM}=$ dry matter. 
to investigate the effects of a change in beef carcass price, calf purchase price and finishing concentrate price on the profitability of each of the systems. Land was assumed to be owned and family labour was assumed to be freely available; thus, no imputed costs for these resources were included in the analysis.

\section{Statistical analysis}

Normality of data distribution was tested using the UNIVARIATE procedure of SAS (Statistical Analysis System, version 9.3, 2011; SAS Institute Inc., Cary, NC, USA). The experimental unit was animal for all variables, except for CDMI during the finishing period, wherein pen was the experimental unit. Data was analysed using the MIXED procedure of SAS. Fixed effects for breed, concentrate supplementation level during the grazing season, finishing strategy and interactions were included in the model. Interactions were found to be non-significant and were subsequently removed from the model. Block was included as a random effect. Initial live weight at the beginning of the experimental period was included as a covariate. Least squares means were used in the procedure to compare differences between concentrate supplementation level during the grazing season and finishing strategy. The PDIFF option and Tukey's procedure were applied as appropriate to evaluate pairwise comparisons between the treatment means. Treatment effects were considered statistically significant when Type I error rate was $<0.05$. Least squares means are reported with standard error of the mean (s.e.) to facilitate interpretation of the treatment means.

\section{Results}

\section{Feed analysis and estimates of CDMI}

The chemical composition of the concentrate offered throughout the experimental period, the pasture offered during the grazing season and grass silage offered to the SC group during the finishing period are presented in Table 2 . During the grazing season, the HA and LA groups consumed 325 and $161 \mathrm{~kg} \mathrm{DM}$ of concentrates/head, respectively. CDMI during the finishing period was $78 \mathrm{~kg} D M /$ head greater $(P<$ 0.001 ) for HA compared to that for LA, i.e. 1,283 and $1,205 \mathrm{~kg}$ DM, respectively. Similarly, CDMI during the finishing period was $442 \mathrm{~kg}$ greater $(P<0.001)$ for AL compared to that for $\mathrm{SC}$, namely, 1,465 and 1,023 kg DM, respectively.

\section{Animal and carcass performance}

At housing, HA were $16 \mathrm{~kg}$ heavier $(P<0.05)$ than LA as the ADG during the grazing season was $0.10 \mathrm{~kg}$ greater $(P$ $<0.01$ ) for HA (Table 3). Live weight at slaughter was similar for LA and HA, but the carcass weight tended $(P=0.08)$ to be greater for $\mathrm{HA}$ compared to that for $\mathrm{LA}$. During the finishing period, the ADG tended $(P=0.09)$ to be greater for LA than for HA. Lifetime ADG and live weight/d of age were similar for HA and LA. However, carcass weight/d of age tended to be greater $(P=0.06)$ for HA than for LA. Kill-out proportion tended to be greater $(P=0.07)$ for HA than for LA. Conformation score and the perinephric and retroperitoneal fat, both absolute and expressed as a proportion of carcass weight, were similar for HA and LA. The HA treatment group had a 0.56 unit greater $(P<0.05)$ fat score compared to the LA group.

Live weight at housing was similar for AL and SC. Live weight at slaughter $(P<0.001)$ and carcass weight $(P<0.001)$ were $41 \mathrm{~kg}$ and $23 \mathrm{~kg}$ greater, respectively, for AL compared to the same for SC. ADG during the grazing season was similar for $A L$ and $S C$, but $A D G$ during the finishing period was $0.21 \mathrm{~kg}$ greater $(P<0.001)$ for $A L$ than for SC. Lifetime ADG was $0.12 \mathrm{~kg}$ greater $(P<0.001)$ for $\mathrm{AL}$ than for $\mathrm{SC}$. Consequently, both live weight $(P<0.001)$ and carcass weight $(P<0.001) / \mathrm{d}$ of age were greater for $A L$ than for SC. Kill-out proportion was similar for AL and SC. Conformation score $(P<0.05)$ and fat score $(P<0.06)$ were greater for AL than for SC. Perinephric and retroperitoneal fat was $2.39 \mathrm{~kg}$ heavier $(P<0.001)$ for $\mathrm{AL}$ than for SC. When expressed as per-kilogram carcass weight, perinephric and retroperitoneal fat was $15 \%$ greater for AL compared to that for SC $(P<0.01)$.

\section{Carcass measurements}

Carcass length $(P=0.09)$ tended to be greater for HA than for LA (Table 4). Carcass depth $(P<0.05)$ and leg length $(P<$ 0.05 ) were greater for HA compared to the same for LA. Leg thickness, leg width and circumference of round were similar for LA and HA. Carcass length $(P<0.01)$ and leg thickness $(P$ $<0.001$ ) were greater for AL than for SC. Finishing strategy had no effect on carcass depth, leg length, leg width or circumference of round.

When expressed as a proportion of carcass weight, carcass measurements were unaffected by the level of concentrate supplementation during the grazing season. Relative to carcass weight, carcass length $(P<0.001)$, carcass depth $(P<0.001)$ and leg length $(P<0.001)$ were greater for SC than for AL. Similarly, leg thickness $(P<0.05)$, leg width $(P<$ $0.001)$ and circumference of round $(P<0.001)$ were greater for $S C$ than for $A L$ when expressed as a proportion of carcass weight.

\section{Composition of the rib joint}

Concentrate supplementation level during the grazing season had no effect on the area of the $M$. longissimus, weight of the rib joint or composition of the rib joint (Table 5). The area of the M. longissimus was similar for $\mathrm{AL}$ and $\mathrm{SC}$; however, the weight of the rib joint was $0.94 \mathrm{~kg}$ greater $(P<0.001)$ for AL compared to that for SC. The muscle proportion of the rib 
Table 2. Chemical composition of the feed offered throughout the experimental period

\begin{tabular}{lccc}
\hline & Grazed grass & Concentrate $^{\text {Grass silage }}{ }^{1}$ & 25.6 \\
\hline DM (\%) & 17.3 & 84.0 & 55.3 \\
Crude ash (g/kg DM) & 109.8 & 164.3 & 156.5 \\
Crude protein (g/kg DM) & 197.9 & 445.8 & - \\
Starch (g/kg DM) & - & 137.9 & 492.7 \\
Neutral detergent fibre (g/kg DM) & 456.8 & - & 678.5 \\
DM digestibility (g/kg DM) & 768.1 & - & 656.6 \\
Organic matter digestibility (g/kg) & 766.0 & - & - \\
Water soluble carbohydrates (g/kg DM) & 104.4 & \\
\hline
\end{tabular}

${ }^{1}$ Values for grass silage offered during the finishing period.

$\mathrm{DM}=$ dry matter.

Table 3. Effects of supplementation level and finishing strategy on body weight, average daily gain and carcass performance of dairy bulls

\begin{tabular}{|c|c|c|c|c|c|c|c|}
\hline & \multicolumn{2}{|c|}{ Supplementation level ${ }^{1}$ (S) } & \multicolumn{2}{|c|}{ Finishing strategy ${ }^{2}(F)$} & \multirow[t]{2}{*}{ s.e. } & \multicolumn{2}{|c|}{ Significance $^{3}$} \\
\hline & LA & HA & $A L$ & SC & & $\mathbf{S}$ & $\mathbf{F}$ \\
\hline Initial weight (kg) & 87 & 84 & 87 & 84 & 2.0 & - & - \\
\hline Housing weight $(\mathrm{kg})$ & 214 & 230 & 223 & 221 & 4.5 & * & - \\
\hline Live weight at slaughter (kg) & 455 & 469 & 483 & 442 & 7.0 & - & $* * *$ \\
\hline Carcass weight $(\mathrm{kg})$ & 230 & 240 & 247 & 224 & 3.9 & 0.0834 & $* * *$ \\
\hline \multicolumn{8}{|l|}{ Average daily gains $(\mathrm{kg})$} \\
\hline First season at pasture & 0.78 & 0.88 & 0.84 & 0.82 & 0.024 & ** & - \\
\hline Finishing period & 1.28 & 1.21 & 1.35 & 1.14 & 0.028 & 0.0896 & $* * *$ \\
\hline Lifetime gain & 1.01 & 1.04 & 1.09 & 0.97 & 0.017 & - & *** \\
\hline Live weight/d of age & 0.99 & 1.02 & 1.05 & 0.96 & 0.015 & - & $* * *$ \\
\hline Carcass weight/d of age & 0.50 & 0.52 & 0.54 & 0.49 & 0.008 & 0.0616 & $* * *$ \\
\hline \multicolumn{8}{|l|}{ Carcass performance } \\
\hline Kill-out proportion (g/kg) & 506 & 511 & 511 & 506 & 2.1 & 0.0696 & - \\
\hline Conformation score (1-15) & 4.69 & 4.79 & 5.00 & 4.49 & 0.152 & - & * \\
\hline Fat score $(1-15)$ & 4.87 & 5.43 & 5.41 & 4.89 & 0.170 & * & * \\
\hline Perinephric + retroperitoneal fat $(\mathrm{kg})$ & 8.55 & 9.28 & 10.11 & 7.72 & 0.390 & - & $* * *$ \\
\hline Perinephric + retroperitoneal fat $/ \mathrm{kg}$ carcass weight ( $\mathrm{g} / \mathrm{kg}$ carcass) & 37.1 & 38.4 & 40.8 & 34.6 & 1.52 & - & ** \\
\hline
\end{tabular}

${ }^{1}$ Concentrate supplementation level during the grazing season; LA = $1 \mathrm{~kg}$ DM of concentrates/head daily; HA = $2 \mathrm{~kg}$ DM of concentrates/ head daily.

${ }^{2}$ Finishing strategy; $\mathrm{AL}=$ concentrates ad libitum; $\mathrm{SC}=$ grass silage plus $5 \mathrm{~kg} \mathrm{DM}$ of concentrates/head daily.

${ }^{3}$ Interactions between concentrate supplementation level during the grazing season and finishing strategy were found to be non-significant and thus were omitted.

joint was $13 \%$ greater for AL than for SC $(P<0.001)$. The proportion of bone in the rib joint was similar for both finishing strategies.

Concentrate supplementation level during the grazing season had no effect on the area of the $M$. longissimus, weight of the rib joint or the muscle and bone proportions of the rib joint when expressed as a proportion of carcass weight. Scaled to carcass weight, the area of the $M$. longissimus was greater $(P$ $<0.05)$ for SC than for AL. However, rib weight tended $(P=$ $0.05)$ to be greater for AL than for SC. Although no difference was observed between $A L$ and SC for bone proportion of the rib joint relative to carcass weight, the muscle proportion of the rib joint relative to carcass weight was greater for AL than for SC $(P<0.05)$.

\section{Economics}

Increasing the level of concentrate supplementation during the grazing season resulted in a gross output value greater by $€ 45$ (Table 6). However, concentrate feed costs and total variable costs increased by $€ 110 /$ head and $€ 93 /$ head, 
Table 4. Effects of supplementation level and finishing strategy on absolute carcass measurements and as a proportion of carcass weight

\begin{tabular}{|c|c|c|c|c|c|c|c|}
\hline & \multicolumn{2}{|c|}{ Supplementation level ${ }^{1}$ (S) } & \multicolumn{2}{|c|}{ Finishing strategy ${ }^{2}(F)$} & \multirow[t]{2}{*}{ s.e. } & \multicolumn{2}{|c|}{ Significance $^{3}$} \\
\hline & LA & HA & AL & Sc & & $\mathbf{s}$ & $\mathbf{F}$ \\
\hline \multicolumn{8}{|c|}{ Absolute carcass measurements $(\mathrm{cm})$} \\
\hline Carcass length & 125 & 127 & 128 & 125 & 0.6 & 0.0946 & ** \\
\hline Carcass depth & 45 & 46 & 45 & 45 & 0.3 & * & - \\
\hline Leg length & 65 & 66 & 66 & 66 & 0.4 & * & - \\
\hline Leg thickness & 24 & 24 & 25 & 23 & 0.3 & - & *** \\
\hline Leg width & 42 & 43 & 43 & 42 & 0.3 & - & - \\
\hline Circumference of round & 109 & 110 & 110 & 109 & 0.6 & - & - \\
\hline \multicolumn{8}{|c|}{ Carcass measurements expressed as a proportion of carcass weight ( $\mathrm{mm} / \mathrm{kg}$ carcass) } \\
\hline Carcass length & 5.50 & 5.35 & 5.23 & 5.62 & 0.074 & - & *** \\
\hline Carcass depth & 1.96 & 1.92 & 1.86 & 2.02 & 0.032 & - & *** \\
\hline Leg length & 2.86 & 2.80 & 2.71 & 2.95 & 0.036 & - & *** \\
\hline Leg thickness & 1.04 & 1.02 & 1.00 & 1.05 & 0.013 & - & * \\
\hline Leg width & 1.86 & 1.81 & 1.76 & 1.91 & 0.024 & - & $* * *$ \\
\hline Circumference of round & 4.77 & 4.65 & 4.51 & 4.90 & 0.057 & - & *** \\
\hline
\end{tabular}

${ }^{1}$ Concentrate supplementation level during the grazing season; LA = $1 \mathrm{~kg}$ DM of concentrates/head daily; HA = $2 \mathrm{~kg}$ DM of concentrates/ head daily.

${ }^{2}$ Finishing strategy; $\mathrm{AL}=$ concentrates ad libitum; $\mathrm{SC}=$ grass silage plus $5 \mathrm{~kg}$ DM of concentrates/head daily.

${ }^{3}$ Interactions between concentrate supplementation level during the grazing season and finishing strategy were found to be non-significant and thus were omitted.

Table 5. Effects of supplementation level and finishing strategy on the rib joint and its composition

\begin{tabular}{|c|c|c|c|c|c|c|c|}
\hline & \multicolumn{2}{|c|}{ Supplementation level ${ }^{1}$ (S) } & \multicolumn{2}{|c|}{ Finishing strategy ${ }^{2}(F)$} & \multirow[t]{2}{*}{ s.e. } & \multicolumn{2}{|c|}{ Significance $^{3}$} \\
\hline & LA & HA & $A L$ & Sc & & $\mathbf{s}$ & $\mathbf{F}$ \\
\hline M. longissimus area $\left(\mathrm{cm}^{2}\right)$ & 60.89 & 62.45 & 62.81 & 60.52 & 1.23 & - & - \\
\hline Weight of rib joint (kg) & 6.71 & 6.91 & 7.28 & 6.34 & 0.146 & - & $* * *$ \\
\hline \multicolumn{8}{|l|}{ Composition of rib joint $(\mathrm{kg})$} \\
\hline Muscle & 4.90 & 5.10 & 5.36 & 4.64 & 0.112 & - & $* * *$ \\
\hline Bone & 1.93 & 1.90 & 1.96 & 1.87 & 0.043 & - & - \\
\hline \multicolumn{8}{|l|}{ Expressed as a proportion of carcass weight } \\
\hline M. longissimus area ( $\mathrm{cm}^{2} / \mathrm{kg}$ carcass) & 0.27 & 0.26 & 0.26 & 0.27 & 0.004 & - & * \\
\hline Weight of rib joint (g/kg carcass) & 29.1 & 28.7 & 29.5 & 28.4 & 0.42 & - & 0.0523 \\
\hline \multicolumn{8}{|l|}{ Composition of rib joint (g/kg carcass) } \\
\hline Muscle & 2.1 & 2.1 & 2.2 & 2.1 & 0.03 & - & * \\
\hline Bone & 8.4 & 8.0 & 8.0 & 8.4 & 0.02 & - & - \\
\hline
\end{tabular}

${ }^{1}$ Concentrate supplementation level during the grazing season; LA = $1 \mathrm{~kg}$ DM of concentrates/head daily; HA = $2 \mathrm{~kg}$ DM of concentrates/ head daily.

${ }^{2}$ Finishing strategy; $\mathrm{AL}=$ concentrates ad libitum; $\mathrm{SC}=$ grass silage plus $5 \mathrm{~kg}$ DM of concentrates/head daily.

${ }^{3}$ Interactions between concentrate supplementation level during the grazing season and finishing strategy were found to be non-significant and thus were omitted.

respectively. Thus, gross margin was $€ 48 /$ head greater for LA than for HA. Total fixed costs were similar for both levels of concentrate supplementation and, therefore, the net margin was greater by $€ 49 /$ head for LA compared to that for HA.

Beef price received was $€ 0.08 / \mathrm{kg}$ greater $(P<0.05)$ for $\mathrm{AL}$ than for SC. Concentrate feed costs were $€ 162 /$ head greater for $\mathrm{AL}$ than for SC. Consequently, concentrate feed costs represented $72 \%$ and $65 \%$ of the total variable costs for AL and SC, respectively. Other feed costs (grazed grass and grass silage) were $€ 17 /$ head greater for $S C$ than for $A L$. The remaining variable costs were similar for $A L$ and $S C$. The total cost to produce a kilogram of beef carcass was $€ 0.29 / \mathrm{kg}$ 
Table 6. Economic appraisal $(€ /$ head, with the exception of beef carcass price) of dairy bulls slaughtered at 15 mo of age

\begin{tabular}{|c|c|c|c|c|}
\hline Production systems & LA $^{1}$ & $\mathrm{HA}^{2}$ & $A L^{3}$ & $\mathrm{SC}^{4}$ \\
\hline Beef carcass price ( $€ / \mathrm{kg}$ carcass) & 3.77 & 3.83 & 3.84 & 3.76 \\
\hline Livestock sales & 869 & 914 & 941 & 842 \\
\hline Calf purchase price & 100 & 100 & 100 & 100 \\
\hline Gross output value & 769 & 814 & 841 & 742 \\
\hline \multicolumn{5}{|l|}{ Variable costs } \\
\hline Concentrates & 553 & 643 & 679 & 517 \\
\hline Other feedstuff & 122 & 121 & 114 & 130 \\
\hline Veterinary and medical & 61 & 61 & 61 & 61 \\
\hline Other & 90 & 93 & 94 & 89 \\
\hline Total variable costs & 826 & 919 & 949 & 796 \\
\hline Gross margin & $(57)$ & (105) & $(108)$ & $(54)$ \\
\hline Total fixed costs & 131 & 133 & 134 & 130 \\
\hline Net margin & (189) & (238) & $(242)$ & $(185)$ \\
\hline \multicolumn{5}{|l|}{ Sensitivity analysis } \\
\hline \multicolumn{5}{|l|}{ Impact on margin/head $(€)$} \\
\hline Calf purchase price ( $\pm € 10 /$ head) & 9.50 & 9.50 & 9.50 & 9.50 \\
\hline Finishing concentrate price $( \pm € 10 / t)$ & 14.30 & 15.30 & 17.40 & 12.20 \\
\hline Beef price $( \pm € 0.10 / \mathrm{kg})$ & 23.00 & 23.90 & 24.50 & 22.40 \\
\hline
\end{tabular}

$11 \mathrm{~kg} \mathrm{DM}$ of concentrates/head daily during the grazing season.

${ }^{2} 2 \mathrm{~kg}$ DM of concentrates/head daily during the grazing season.

${ }^{3}$ Finished on concentrates ad libitum.

${ }^{4}$ Finished on grass silage ad libitum plus $5 \mathrm{~kg}$ DM of concentrates/head daily.

$\mathrm{DM}=$ dry matter.

greater for AL compared to that for SC, i.e. $€ 4.43$ and $€ 4.14 / \mathrm{kg}$ carcass, respectively. Gross margin/head was $€ 54$ greater for SC compared to that for AL; however, both finishing strategies returned negative gross margins.

Taking the varying levels of concentrate supplementation and finishing into account, net margins/head were negative for all systems (Figure 1). The differential between the highest and lowest net margin/head was $€ 107$. Dairy bulls in the LA treatment group finished in the SC treatment group returned a net margin of $-€ 159 /$ head, while bulls in the HA treatment group finished in the AL treatment group returned a net margin of $-€ 266 /$ head. Figure 1 also shows that when concentrate costs as a proportion of total variable reduces, the net margin increases.

Sensitivity analysis showed that an increase in calf purchase price of $€ 10 /$ head reduced the net margin by $€ 9.50$ (Table 6 ). When concentrate feed costs increased by $€ 10 / t$, the financial loss was $€ 5.20$ greater for AL than for SC. When beef price increased by $€ 0.10 / \mathrm{kg}$, net margin increased by $10 \%$ and $12 \%$ for AL and SC, respectively.

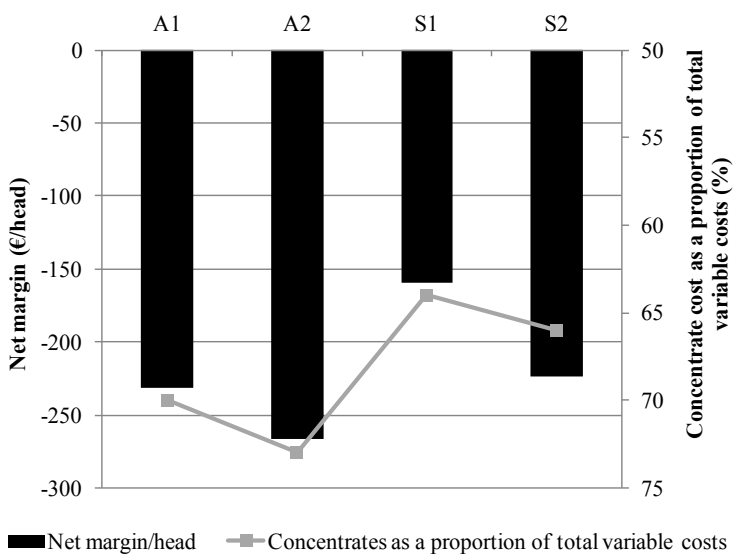

Figure 1. Effects of production system on the net margin/head and the concentrate costs as a proportion of total variable costs of dairy bulls (ad libitum concentrates finished and offered $1 \mathrm{~kg}$ DM of concentrates during the grazing season (A1); ad libitum concentrates finished and offered $2 \mathrm{~kg} \mathrm{DM}$ of concentrates during the grazing season (A2); finished on silage plus $5 \mathrm{~kg}$ DM of concentrates and offered $1 \mathrm{~kg}$ DM of concentrates during the grazing season (S1); finished on silage plus $5 \mathrm{~kg}$ DM of concentrates and offered $2 \mathrm{~kg} \mathrm{DM}$ of concentrates during the grazing season (S2)). DM = dry matter. 


\section{Discussion}

Finishing male cattle as bulls at $<16$ mo of age meets the required UK market specification for bull beef (Matthews, 2011); however, no study has been undertaken to investigate the impacts of alternative production strategies designed to meet this specification or, consequently, to assess the financial feasibility of such production strategies. To address this lack of information, this study assessed the impact of varying levels of concentrate supplementation during the grazing season, alternative finishing strategies and the overall farm profitability of these systems using performance data from dairy bulls.

\section{Level of concentrate supplementation during the grazing season}

Typically, calves in Ireland are managed at pasture during the first season, during which moderate levels of performance $(0.70-0.80 \mathrm{~kg} / \mathrm{d}$ ) are achieved (Campion et al., 2009). However, in the UK and continental Europe, young bull production systems are usually operated as indoor confinement systems, wherein concentrate inputs are high from an early age, with limited proportions of grazed grass included in the diet (Grundy et al., 2000; Nogalski et al., 2014). The findings of the current study are consistent with previous research in which calves grazing under Irish conditions exhibited moderate levels of performance during the grazing season (Campion et al., 2009). The potential to further increase the ADG, from weaning to 9 mo of age, through high concentrate input diets also exists. Keane (2001) reported that HF calves in a barley beef production system gained $1.32 \mathrm{~kg} / \mathrm{d}$ from $12 \mathrm{wk}$ to $9 \mathrm{mo}$ of age when fed indoors on concentrates ad libitum. Calves supplemented with lower levels of concentrate supplementation at pasture showed reduced performance in the current study, but the profitability of the system increased due to savings on feed, which is consistent with the findings of Crosson et al. (2009). Utilising pasture in a 15-mo bull production system can reduce the overall costs of production, but this also presents the challenge of achieving the required market specifications. Although numerous studies have investigated the effects of calf nutrition on performance during the finishing period, many of those studies focussed on the influence of pre-weaning nutrition (Arthington et al., 2005; Wolcott et al., 2010). Wolcott et al. (2010) reported that suckled Shorthorn calves weaned at $259 \mathrm{~d}$ of age were $17 \mathrm{~kg}$ heavier at the start of the finishing period and had $18 \mathrm{~kg}$ greater carcass weight at 23 mo of age compared to those weaned at $123 \mathrm{~d}$ of age. Arthington et al. (2005) reported similar ADG results during the finishing period, United States Department of Agriculture (USDA) grade yields and marbling scores for Brahman $\times$ British steers weaned at
89 or $300 \mathrm{~d}$ of age. A review by Berge (1991) reported that at a fixed carcass weight, the initial differences in body composition during calfhood (5-11 mo of age) were generally not significant at slaughter. This is consistent with the findings of Keane and Drennan (1983), who reported that male Friesian calves supplemented with $1.8 \mathrm{~kg} \mathrm{DM} /$ head daily at pasture were $45 \mathrm{~kg}$ heavier than those offered pasture only at 7 mo of age, but carcass weight, kill-out proportion and the conformation and fat scores were similar. In the present study, HA calves were $16 \mathrm{~kg}$ heavier at housing, yet live weight at slaughter was similar for both groups, while kill-out proportion and carcass weight tended to be greater for $\mathrm{HA}$ and carcass fat score was greater for $\mathrm{HA}$ compared to those for LA. The differences in performance of calves between the Keane and Drennan study (1983) and the present study may be attributed to the age at slaughter. Keane and Drennan (1983) studied animals slaughtered at 22 mo of age, which would have facilitated compensatory growth over an extended period, compared to the approach used in the current study.

\section{Finishing strategy}

Carcass weights of bulls in both finishing strategies in the current study were below target market specifications. The performance of male dairy cattle finished on various finishing strategies has been well documented (Keane and Fallon, 2001; Keane et al., 2006). The findings from the current study are consistent with previous reports, in which animals finished on high concentrate diets had greater ADG, live weight at slaughter and carcass weight, conformation and fat scores compared to animals finished on a combination of grass silage ad libitum plus concentrates (Keane and Fallon, 2001; Keane et al., 2006). In the present study, ADG during the finishing period for bulls finished on concentrates ad libitum was similar to the report of Keane and Fallon (2001), wherein HF bulls (9-11 mo of age), gained up to $1.4 \mathrm{~kg} / \mathrm{d}$ on a high concentrate diet. Grundy et al. (2000) also reported that dairy beef crossbred bulls finished on concentrates ad libitum for approximately $200 \mathrm{~d}$ achieved an ADG of $1.43 \mathrm{~kg}$. Consistent with the present study, Keane and Allen (1998) reported an ADG during the finishing period of $1.18 \mathrm{~kg}$ for Charolais $\times$ dairy bulls finished on grass silage plus concentrates, whereby the proportion of concentrates constituted up to $55 \%$ of total DM intake. However, bulls in that study were finished over a 12mo period and slaughtered at 19 mo of age. Similarly, McGee et al. (2005) reported an ADG during the finishing period of $1.04 \mathrm{~kg}$ for Holstein, Friesian and Charolais $x$ dairy bulls finished over a 10-mo period on a grass silage ad libitum diet supplemented with $6 \mathrm{~kg}$ of concentrates/head daily.

In the present study, the AL group gained an additional $39 \mathrm{~kg}$ live weight during the finishing period compared to the SC group, which resulted in an additional $23 \mathrm{~kg}$ carcass weight. Similarly, Keane and Fallon (2001) reported an additional 
$49 \mathrm{~kg}$ live weight at slaughter, which resulted in additional $34 \mathrm{~kg}$ greater carcass weight for bulls finished on concentrates ad libitum compared to those on grass silage ad libitum plus $6 \mathrm{~kg}$ of concentrates/head daily. Sami et al. (2004) also reported that live weight at slaughter and carcass weights were 48 and $35 \mathrm{~kg}$ greater for Simmental bulls finished for $100 \mathrm{~d}$ on maize silage plus $3.73 \mathrm{~kg}$ DM of concentrates/d compared to those on maize silage plus $0.89 \mathrm{~kg} D M$ of concentrates $/ \mathrm{d}$, respectively. Previous research (Keane and Fallon, 2001; Keane et al., 2006) has shown that animals finished on a high concentrate diet had a greater kill-out proportion compared to those finished on a forage and concentrate diet. Keane and Fallon (2001) reported a $13 \mathrm{~g} / \mathrm{kg}$ greater kill-out proportion for bulls finished on concentrates ad libitum compared to those on a grass silage ad libitum diet supplemented with $6 \mathrm{~kg}$ of concentrates. Similarly, Keane et al. (2006) reported a $10 \mathrm{~g} / \mathrm{kg}$ greater kill-out proportion for dairy and dairy beef crossbred steers finished on concentrates ad libitum compared to those on grass silage plus concentrates (ratio 25:75 on a DM basis). The greater kill-out proportion in those studies could be explained by differences in diet composition, where a forage diet would increase gut fill to a greater degree than a high concentrate diet (Kirkland et al., 2007).

In the current study, carcass conformation and fat scores were greater for AL compared to the same for SC. Sami et al. (2004) reported greater carcass conformation and fat scores for Simmental bulls finished on maize silage supplemented with $3.73 \mathrm{~kg} \mathrm{DM}$ of concentrates compared to those finished on maize silage plus $0.89 \mathrm{~kg}$ DM concentrates. Similarly, Keane and Fallon (2001) reported greater carcass conformation and fat scores for HF bulls finished on concentrates ad libitum compared to those finished on grass silage supplemented with $3 \mathrm{~kg}$ of concentrates DM/head daily. However, Cerdeño et al. (2006) reported similar carcass conformation scores with greater fat scores for 10-mo-old Limousin crossbred bulls finished on concentrates ad libitum compared to those on alfalfa hay supplemented with $4 \mathrm{~kg}$ of concentrates/head daily over a $60-d$ period. The similar conformation score for bulls described by Cerdeño et al. (2006) may be due to the shorter finishing period (60 d) compared to that in the current study.

\section{Economics}

The optimum production system is one that returns a profit by efficiently utilising grazed grass, farm facilities and labour. Economic analysis in the present study showed that net margins were negative for both finishing strategies. The cost to produce $1 \mathrm{~kg}$ of beef was 1.15 and 1.10 times that of the beef price for the AL and SC groups, respectively. Previously, Ashfield et al. (2014b) reported that feed costs represented $74 \%$ of the total variable costs across a range of dairy calfto-beef production systems. Although the utilisation of grazed grass is central to increasing profitability (Crosson et al.,
2009), the 15-mo bull production system is dependent on high levels of concentrate input. Consequently, the proportion of grazed grass in the feed budget is limited. In the current study, $35 \%$ and $38 \%$ of the total lifetime weight gain was estimated to come from grazed grass for $\mathrm{AL}$ and SC, respectively. Although beef carcass price is typically greater in May and June (DAFM, 2015) when spring-born bulls finished at $15 \mathrm{mo}$ of age are slaughtered, the profitability of the system was still negative. Results from the current study also indicated that fluctuations in calf purchase price do not result in re-ranking between the finishing strategies. However, it is clear that $\mathrm{AL}$ is more susceptible to changes in concentrate price than SC, while changes in beef price have the largest effects on the profitability for all systems.

Keane and Fallon (2001) showed that HF bulls, 9-11 mo of age, had the capacity to grow up to $1.4 \mathrm{~kg} / \mathrm{d}$ when finished on a high concentrate diet $(270 \mathrm{~kg}$ live weight gain over a 200 d finishing period in the context of a 15-mo bull production system). Therefore, to achieve a carcass weight of $270 \mathrm{~kg}$, i.e. an approximate live weight at slaughter of $520 \mathrm{~kg}$ in a $15-\mathrm{mo}$ bull production system, the ADG during the grazing season must be greater than that achieved in the current study to ensure that housing weight at the end of the grazing season is approximately $250 \mathrm{~kg}$. This is supported by Kelly et al. (2013), who reported that a minimum live weight of $240 \mathrm{~kg}$ at $35 \mathrm{wk}$ of age would be necessary for dairy bulls to be considered for the 15-mo bull production system. To ensure that these targets are achieved, calves could be supplemented with greater levels of concentrate supplementation at pasture or housed earlier to prolong the finishing period, to ensure that the target live weight at slaughter is achieved. However, both alternatives would increase the costs of production. That aside, assuming that calves were supplemented with $1 \mathrm{~kg}$ of concentrates during the grazing season, finished on a concentrates ad libitum diet and achieved the target carcass weight ( $270 \mathrm{~kg}$ ), a net loss of $€ 149 /$ head would be incurred at the assumed concentrate price.

From a practical perspective, alternative production system(s) would be required on a farm to complement the 15-mo bull production system as modest levels of grazed pasture and grass silage are required. However, Ashfield et al. (2014b) reported that combining production systems for male dairy calves did not improve the utilisation of the grass grown or the profit. Although animal performance of bulls slaughtered at 15 mo of age could be optimised by utilising high levels of grazed pasture via the incorporation of a leader-follower system and/or strategic supplementation with concentrates during periods of reduced pasture quality, results from the current study indicate that alternatives to the 15-mo bull production system, such as the 19-mo bull or 24-mo steer production systems (Ashfield et al., 2014b), should be considered for male dairy calf-to-beef production. 


\section{Conclusion}

Results from this study indicate that calves supplemented with high levels of concentrates at pasture were heavier at housing, but net margin was greater for calves supplemented with lower levels of concentrates. The superior biological performance of animals finished on a higher plane of nutrition was confirmed in this study. The target market specifications were not achieved for any of the systems examined, and all treatments failed to return a positive net margin. Therefore, at the prices assumed in this study, alternative production systems to the 15-mo bull production system should be considered for male dairy calves.

\section{Acknowledgements}

This project (11/SF/322, "BullBeef") was funded by the Irish Department of Agriculture, Food and the Marine's competitive research programmes. The authors also wish to acknowledge the technical support of Brendan Swan and the farm staff at the Teagasc Johnstown Castle Research Centre for the care and husbandry of the animals.

\section{References}

Arthington, J.D., Spears, J.W. and Miller, D.C. 2005. The effect of early weaning on feedlot performance and measures of stress in beef calves. Journal of Animal Science 83: 933-939.

Ashfield, A., Crosson, P. and Wallace, M. 2013. Simulation modelling of temperate grassland based dairy calf to beef production systems. Agricultural Systems 115: 41-50.

Ashfield, A., Wallace, M. and Crosson, P. 2014a. Economic comparison of pasture based dairy calf-to-beef production systems under temperate grassland conditions. International Journal of Agricultural Management 3: 175-186.

Ashfield, A., Wallace, M., Prendiville, R. and Crosson, P. 2014b. Bioeconomic modelling of male Holstein-Friesian dairy calf-to-beef production systems on Irish farms. Irish Journal of Agricultural and Food Research 53: 133-147.

Berge, P. 1991. Long-term effects of feeding during calfhood on subsequent performance in beef cattle (a review). Livestock Production Science 28: 179-201.

Binder, T.D., Schupp, A.R., Mohamad, A.B., Rumore, N.C., Montgomery, R.E., Bagley, C.P. and McMillin, K.W. 1986. Acceptability of beef from Angus-Hereford or Angus-Hereford-Brahman steers finished on all-forage or high energy diet. Journal of Animal Science 62: 381-387.

Bord Bia. 2016a. "Cattle Throughput Graph". Bord Bia, Dublin, Ireland. Available online: http://www.bordbia.ie/industry/farmers/pri- cetracking/cattle/pages/throughput.aspx [Accessed 21 December 2016].

Bord Bia. 2016b. "Export Performance and Prospects 2015/2016". Bord Bia, Dublin, Ireland, 16. Available online: http://www.bordbia. ie/industry/manufacturers/insight/publications/MarketReviews/ Documents/Export-Performance-and-Prospects-2016.pdf [Accessed 21 December 2016], 56 pages.

Campion, B., Keane, M.G., Kenny, D.A. and Berry, D.P. 2009. Evaluation of estimated genetic merit for carcass weight in beef cattle: live weights, feed intake, body measurements, skeletal and muscular scores, and carcass characteristics. Livestock Science 126: 87-99.

Cerdeño, A., Vieira, C., Serrano, E., Lavín, P. and Mantecón, A.R. 2006. Effects of feeding strategy during a short finishing period on performance, carcass and meat quality in previously-grazed young bulls. Meat Science 72: 719-726.

Commission of the European Communities. 1982. European Communities Beef Carcass Classification Regulations. Council Regulations 1358/80, 1208/81, 1202/82. Commission Regulations 2930/81, 563/82, 1557/82. Brussels. Belgium.

Connolly, L., Kinsella, A., Quinlan, G. and Moran, B. 2010. "Teagasc National Farm Survey”, Dublin, Ireland. Available online: https:// www.teagasc.ie/publications/2011/national-farm-survey-2010.php [Accessed 19 December 2016], 103 pages.

Crosson, P., McGee, M. and Drennan, M.J. 2009. The economic impact of turnout date to pasture in spring of yearling cattle on suckler beef farms. Proceeding of the Agricultural Research Forum, Tullamore, Ireland, page 77.

CSO (Central Statistics Office). 2015. "Agricultural Input and Output Absolute Prices by Month and Statistic”. Central Statistics Office, Dublin, Ireland. Available online: http://www.cso.ie/px/pxeirestat/ Database/eirestat/Agricultural\%20Input $\% 20$ and $\% 20$ Output $\% 20$ Absolute $\% 20$ Prices/Agricultural\%20Input $\% 20$ and $\% 20$ utput $\% 20$ Absolute $\% 20$ Prices_statbank.asp?SP=Agricultural $\% 20$ Input $\% 20$ and $\% 20$ Output $\% 20$ Absolute $\% 20$ Prices\&Planguage $=0$ [Accessed 05 January 2017].

DAFM (Department of Agriculture Food and the Marine). 2010. "Food Harvest A Vision for Irish Agri-Food and Fisheries 2020". Department of Agriculture, Food and the Marine, Agriculture House, Dublin 2, Ireland.

DAFM. 2015. "Beef Factory Prices Weekly Report 2014". Department of Agriculture, Food and the Marine. Dublin. Ireland. Available online: http://www.agriculture.gov.ie/farmingsectors/beef/beeffactorypricesweeklyreports/[Accessed 05 January 2017].

Dawn Meats. 2011. Dawn Direct 2, September 2011. Available online: http://www.dawnmeats.com/index.php/downloads/ viewcategory/10-dawn-direct-ireland?start=10 [Accessed 15 November 2016].

De Boer, H., Dumont, B.L., Pomeroy, R.W. and Weniger, J.H. 1974. Manual on EAAP reference methods for the assessment of carcass characteristics in cattle. Livestock Production Science 1: 151-164. 
European Commission. 2015. "Prospects for EU Agricultural Markets and Income: 2015-2025". Directorate-general for Agriculture and Rural Development. Available online: http://ec.europa.eu/agriculture/markets-and-prices/medium-term-outlook/2015/fullrep_ en.pdf [Accessed 19 December 2016].

Fallon, R.J. 1992. "Calf Rearing”. Teagasc, Dublin, 56 pages.

Finneran, E., Crosson, P., O'Kiely, P., Shalloo, L., Forristal, D. and Wallace, M. 2010. Simulation modelling of the cost of producing and utilising feeds for ruminants on Irish farms. Journal of Farm Management 14: 95-116.

Gardiner, M.J. and Radford, T. 1980. "Soil Associations of Ireland and their Land Use Potential”. An Foras Taluntais, Dublin. Ireland, 143 pages.

Grundy, H.F., Hardy, R., Chapple, D.G. and Davies, M.H. 2000. Performance of late maturing beef $x$ dairy cattle finished on grass silage plus concentrate or all-concentrate diets. Irish Journal of Agricultural and Food Research 39: 409-417.

IFJ (Irish Farmers Journal). 2011. Calf Prices. Irish Farmers Journal all issues from January to March 2011.

Keane, M.G. 2001. "Response in Beef Cattle to Concentrate Feeding”, Occasional Series, No. 3. Teagasc Grange Research Centre, Dunsany, Meath, Ireland.

Keane, M.G. and Allen, P. 1998. Effects of production system intensity on performance, carcass composition and meat quality of beef cattle. Livestock Production Science 56: 203-214.

Keane, M.G. and Drennan, M.J. 1983. Supplementation of grass-fed calves: 3 . Effects of concentrate level and protein content, and subsequent performance to slaughter. Irish Journal of Agricultural Research 22: 113-125.

Keane, M.G. and Fallon, R.J. 2001. Effects of feeding level and duration on finishing performance and slaughter traits of Holstein-Friesian young bulls. Irish Journal of Agricultural and Food Research 40: 145-160.

Keane, M.G., Drennan, M.J. and Moloney, A.P. 2006. Comparison of supplementary concentrate levels with grass silage, separate or total mixed ration feeding and duration of finishing in beef steers. Livestock Science 103: 169-180.

Kelly A.K., Carty D. and Tuffy N. 2013. Lessons learned from the dairy calf to beef programme. Profitable beef from the dairy herd. Proceeding of the Teagasc National Beef Conference, Kilkenny, Ireland, pages 33-37.

Kirkland, R.M., Patterson, D.C., Keady, T.W.J., Moss, B.W. and Steen, R.W.J. 2007. Beef production potential of Norwegian Red and Holstein-Friesian bulls slaughtered at two ages. Animal 1: 1506-1514.
Matthews, K.R. 2011. Review of Published Literature and Unpublished Research on Factors Influencing Beef Quality. Agriculture and Horticulture Development Board, United Kingdom.

McGee, M., Keane, M.G., Neilan, R., Moloney, A.P. and Caffrey, P.J. 2005. Production and carcass traits of high dairy genetic merit Holstein, standard dairy genetic merit Friesian and Charolais $\times$ Holstein-Friesian male cattle. Irish Journal of Agricultural and Food Research 44: 215-231.

Nogalski, Z., Wielgosz-Groth, Z., Purwin, C., Sobczuk-Szul, M., Mochol, M., Pogorzelska-Przybytek, P. and Winarski, R. 2014. Effect of slaughter weight on the carcass value of young crossbred ('Polish Holstein Friesian' $\times$ 'Limousin') steers and bulls. Chilean Journal of Agricultural Research 74: 59-66.

O'Donovan, M., Connolly, J., Dillon, P., Rath, M. and Stakelum, G. 2002. Visual assessment of herbage mass. Irish Journal of Agricultural and Food Research 41: 201-211.

O'Donovan, T. and O'Mahony, J. 2011. "Crops Costs and Returns 2011". Teagasc, Oak Park, Carlow, Ireland

O'Riordan, E.G. and Cormican, P. 2015. "Steer Production: the National Picture". Teagasc Advisory Newsletter, Beef, June.

O'Riordan, E.G., Crosson, P. and McGee, M. 2011. Finishing male cattle from the beef suckler herd. Irish Grassland Association Journal 45: 131-132.

Owens, D., McGee, M., Boland, T. and O'Kiely, P. 2008. Intake, rumen fermentation and nutrient flow to the omasum in beef cattle fed grass silage fortified with sucrose and/or supplemented with concentrate. Animal Feed Science Technology 144: 23-43.

Sami, A.S., Augustini, C. and Schwarz, F.J. 2004. Effects of feeding intensity and time on feed on performance, carcass characteristics and meat quality of Simmental bulls. Meat Science 67: 195-201.

Schneider, C.A., Rasband, W.S. and Eliceiri, K.W. 2012. NIH Image to Image J: 25 years of image analysis. Nature Methods 9: 671-675.

Steen, R.W.J. 1995. The effect of plane of nutrition and slaughter weight on growth and food efficiency in bulls, steers and heifers of three breed crosses. Livestock Production Science 42: 1-11.

Swinbank, A. and Daugbjerg, C. 2006. The 2003 CAP reform: accommodating WTO pressures. Comparative European Policies 4 : 47-64.

Wolcott, M.L., Graser, H.U. and Johnston, D.J. 2010. Effects of early weaning on growth, feed efficiency and carcass traits in Shorthorn cattle. Animal Production Science 50: 315-321. 